\title{
Professional Capital Contested: A Bourdieusian Analysis of Conflicts between Professionals and Managers
}

\author{
Mirko Noordegraaf $^{\mathrm{a}}$ and Willem Schinkel ${ }^{\mathrm{b}}$ \\ a) Professor of Public Management, Utrecht School of Governance, Utrecht University, \\ Bijlhouwerstraat 6, 3511 ZC Utrecht, The Netherlands \\ m.noordegraaf@uu.nl \\ b) Associate Professor of Sociology, Erasmus University, PO Box 1738, \\ 3000 DR Rotterdam, The Netherlands \\ schinkel@fsw.eur.nl
}

\begin{abstract}
Although Bourdieu paid scant attention to (and in fact discredited) the notion of professionalism, his social theory is well-equipped to understand the evolution of professional work. Professionalism can be conceived as a set of symbolic resources that (re)produce an occupational order, favoring expertise and craftsmanship. In neo-liberal economies this order is contested and professional powers are distrusted; professional work is seen as closed-off and conservative. Managers have become important vehicles for rationalizing and innovating production, and improving "value for money." In fact, managerial "fields" are created, and conflicts between managerial and professional fields are well documented. These conflicts are ironic, as new classes of managers seek classic strategies of professionalization as well as classic forms of professional capital for securing managerial positions. They form professional associations, for instance, and invest in schooling, credentials and work codes. This paper explores conflicts between professionals and managers as "contests over symbolic capital." We argue that professional capital is appropriated by managers in order to distinguish "new" from "old" professional work in larger economized fields of power.
\end{abstract}

\section{Keywords}

professionalism, professionalization, Pierre Bourdieu, neo-liberalism, managers 
Traditionally, professions can be seen as groups of workers who control themselves (e.g. Freidson 1994, 2001). Professions determine who may legitimately act as "professional" members and they regulate professional member behavior. They determine professional qualifications, set up training and education programs in order to improve skills and experiences, establish credentials and codes of conduct, and supervise professional behaviors. By investing in associations, education and codes, professions secure the technical content or "base" of professional work as well as its "service ethic" (cf. Wilensky 1964). By investing in jurisdictions, backed by state regulations, they secure professional autonomies (e.g. Abbott 1988) and thus professional powers and status (e.g. Larson 1977; Brint 1994). Classic examples are medical doctors, lawyers, engineers and university professors (e.g. Krause 1996).

Although Bourdieu hardly paid attention to professions and in fact discredited the notion of professionalism (Bourdieu and Wacquant 1992, 1999), his social theory is well-equipped to understand the evolution of professionalism and professional practices. His analysis of social practices and exchanges, and especially his notions of fields, habitus and capital can be used to understand what is going on, and why, when professions are formed to structure work and institutionalize occupations.

In the sea of seemingly self-interested economic exchanges (Bourdieu 2000:19), professions are islands of cultural and social exchange that materialize social services, guard expertise and craftsmanship, symbolize the "goodness" of service provision, and generate material awards for the professional workers concerned. Consequently, Bourdieu's theory enables us to understand the social formation or construction of professional work as well as its distributive effects. His theory, moreover, enables us to connect such social formation to time-specific circumstances, such as economic and political realities. This implies that Bourdieu's theory is also well-suited for understanding the creation of new professional fields and for understanding conflicts within and between professional fields.

Here, we focus on the current conflict between professionals and managers. More particularly, we discuss the rise of professional fields of managers - of new classes of "professional" managers and executives held responsible for running professional service organizations like hospitals. We will describe the rise of managers in these organizations and subsequent conflicts between professionals and managers, and analyze these conflicts as contests over symbolic capital. 
Traditional professionals like medical doctors are increasingly distrusted (e.g. Allsop 2006), and managers are seen as new vehicles for supervising medical doctors and for providing better health care (Harrison and Pollitt 1994; Harrison 2009). In fact, professional service organizations like hospitals are increasingly turned into "managed professional businesses" (Brock et al. 2001). Interestingly, and also ironically, professional managers tend to follow classic strategies of professionalization and seek classic forms of professional capital for securing their new position (e.g. Reed and Anthony 1992; Grey 1997; Noordegraaf 2006, 2007).

From a Bourdieusian perspective these contests over symbolic capital can be explained as contests over the nature of professional work in a larger field of power. The professionalization of managers entails a reconfiguration of professional work, and distinctions between "old" and "new" professional work are drawn. This occurs, we argue, because both professional and managerial fields face economized circumstances; they have to find symbolic means for working amidst tightened conditions and for distributing scarce economic capital. And at the same time, this heightens tensions in the distribution of symbolic capital, equally a scarce form of capital.

Below, we analyze how this happens, first by exploring the nature of classic professionalism; second by approaching classic or pure professionalism in terms of professional capital; third by exploring pressures on professionalism and by describing the rise of professional managers; and fourth by analyzing subsequent conflicts between professionals and managers as contests over symbolic capital in neo-liberal times.

\section{The Formation of Pure Professionalism}

The medical profession, lawyers, engineers and university professors represent "pure professionalism" (cf. Noordegraaf 2007). They succeeded in isolating and optimizing their associational, educational and occupational structures. Backed by states and universities (Thorstendahl and Burrage 1990:207-218), they established stable and protected groups of workers that could rely upon entrance barriers and regulatory mechanisms for standardizing and supervising worker behaviors. They established associations, set up schooling programs, and formalized work structures, including worker careers, so that services could be rendered effectively and legitimately. 
To become a professional worker, then, means more than learning and performing a job. It means one has to be a well-educated and wellbehaving group member. A classic professional is an actor whose habitus is well adjusted to the objective set of relations in which he or she occupies a position. A professional chooses the right study, gets the right qualifications and credentials, keeps his or her skills up-to-date, and behaves properly, according to the logic of the professional field in which (s)he occupies a position (e.g. Freidson 1994). This means, in Bourdieu's terminology, that such a professional field is characterized internally by its own illusio, which prescribes a certain way of dealing with the field-specific substance of professional capital and invests belief in the legitimacy thereof. Externally, it means professionalism is a form of symbolic capital which needs to be maintained. This involves a sens pratique that actors in various professional fields share (compare Bourdieu 1990:82).

In terms of professional behavior this has dual effect: a professional knows what to do when he treats cases as well as what it means to treat cases. This is his or her field-specific "feel for the game," which also allows a person to make a distinction, that is, to gather more symbolic capital. He or she is thus turned into a competent worker with the right skills and techniques as well as into a morally competent worker who behaves responsibly. As indicated, Wilensky (1964:138) discussed this combination by presenting two core features of classic professionalism: professional behavior rests upon a technical base and is guided by a service ethic. Later on Brint (1994:5) spoke of social trustee professionalism, in order to show how knowledgeable professional behavior embodies certain societal values.

In terms of occupational structures, there is a dual effect as well. Internally, a classic profession is well-structured. Despite the fact that professionals possess "professional autonomies," such as clinical autonomies (e.g. Harrison 1999:50-64), professional behaviors are subjected to strict discipline; standards and protocols regulate member behavior. In the words of Brint, professions can be seen as a "form of collective organization" $(1994: 6,23)$.

Externally, however, a profession is isolated and shielded-off from society. It is seen as an autonomous "bastion," which entails certain risks but also offers advantages. The profession-as-bastion is part of an occupational order that acknowledges the value of free, but regulated professional 
workers. When workers have a clear service ethic, there is a regulatory bargain: workers offer good services, for which they receive recognition and status.

As we show elsewhere in this volume, there have been many accounts of the processes by way of which professions are formed, both as "a type of organization" and as a "status category" and "ideology" (cf. Brint 1994:6, 23). It has been tempting to explain such processes in functional terms. Professions are useful for providing certain complex services for which abstract or esoteric knowledge is required (Schön 1983; Freidson 1994); professional groups are part of a societal division of labor that originates from demands for services (e.g. Carr-Saunders 1928; Parsons 1954).

These functional accounts have been resisted by power-centered accounts that focus on the politics of professionalization. Professions become strong when they offer "marketable expertise" (cf. Brint 1994:23) and build strong positions in work "ecologies" by establishing strong "jurisdictions" (Abbott 1988). This needs to be backed by state authorities and partnerships (with universities, for example; Thorstendahl and Burrage 1990: chap. 11), including when they mitigate internal conflicts between professional "segments" (e.g. Bucher and Strauss 1961).

Recently these systemic explanations have been complemented by power-centered strategic explanations. When forming professional practices, it is important to invoke the right discourses, symbols and standards (Watson 2002; Fournier 1999) and to enact the "appearance of professionalism" (e.g. Hodgson 2002, 2005). Without the right language, narrative and categories, it is impossible to (re)produce and regulate professional behavior. Paradoxically, such strategies might not only contribute to professional powers and "free" certain groups of workers; they might also discipline and "responsibilize" these workers (e.g. Grey 1997).

All in all, power-centered approaches have not only changed understandings of professional dynamics in and around classic professions, such as medicine (e.g. Bucher \& Strauss 1961, on conflicts within medical professions). They have also changed understandings of what professionals actually are. In fact, they have distinguished classic or "status" professionalism from other, less pure forms of professionalism, such as practical, bureaucratic and organizational professionalism (e.g. Larson 1977; Noordegraaf 2007). Consequently, they have highlighted the rise and formation 
of new professions, such as accounting, journalism, social work, teaching and consultancy (e.g. Hoyle 1980; Osiel 1986; Covaleski et al. 1988; Randle and Brady 1997; Duyvendak et al. 2006; McKenna 2006).

Although these new "professions" cannot really be compared with classic professionals like medical doctors, they stick to classic professionalization strategies. They try to establish technical bases, service ethics, and jurisdictions, and attempt to establish the appearance and performance of professionalism (e.g. Watson 2002; Hodgson 2005). According to functionalists, these aspiring groups of workers, who lack "pure" forms of professionalism, are not really professionals. At the most, they are low-status or semi-professionals (e.g. Etzioni 1969). According to power-centered scholars, however, these groups of workers can be seen as professionals because they are seen as professionals. Professionalism is socially constructed, never pure and always "hybrid," sometimes to a high extent (see Noordegraaf 2007; compare Reed and Anthony 1992).

\section{Professionalism as Symbolic Capital}

In most of these accounts, authors do not directly rely upon Bourdieu's work, although there are exceptions. In his well-known book Expert Professionalism, for example, Brint now and then refers to Bourdieu - mainly in footnotes - in order to ground his analysis of "professions and professionalism as historically evolving sociological forms" (1994:4-5). He not only shows variation in such forms over time (in the move from "social trustee professionalism" to "expert professionalism") but also across contexts (especially national contexts). Yet, Brint also looks for constants, which he mainly finds by portraying professionals as a "stratum" or "class" with certain cultural make-ups and political aspirations.

For instance, Brint argues that "most professionals share a distinctive matrix of experience by simultaneously occupying the situation of highranking organizational employee, merchant of marketable cultural capital, and specialists in a body of complex learning" (1994:81, italics added). But again, these constants are relative: In the "era of expertise" the "coherence of professional middle class as a force in political life" has declined and a "new expert stratum" has appeared. The latter has "strong interests in marketable knowledge and weaker concerns about relationships between community and authority" $(1994: 13,15)$. This newer stratum is increas- 
ingly "splintered" (1994:11), especially because it is interwoven with organizations, industries and markets.

Comparable searches for links between professional behavior, social classes and society can be found in other works analyzing traditional professional fields, such as law (e.g. Sommerlad 2007); interestingly, we find this also in Bourdieu himself (1987). Bourdieusian traces can also be found in studies of the formation of new, hybrid professional fields, such as accounting (Lee 1995, 1999; Lawrence 2004), journalism (Aldridge and Evetts 2003; Benson 2006) and teaching (Gleeson et al. 2005, Hardy and Lingard 2008), and also - which we will work out below - management (e.g. Useem and Karabel 1986; Reed and Anthony 1992).

But other than this, Bourdieu is largely absent in the mainstream literature on professionalization. This can be explained by his own silence on the subject; apparently, his (French) lack of affinity with free professions, and his dislike of Anglo-Saxon influences led him to ignore the sociology of professions. Nonetheless, this silence is remarkable, as Bourdieu offers many analytical tools to improve our critical understanding of professionalization.

Meanwhile, the mainstream literature on professionalism is full of sharp divisions: between functional and power-centered approaches, between material and symbolic understandings, and between systemic and strategic outlooks. By contrast, Bourdieu's social theory, which he characterizes as "constructivist structuralism" (Bourdieu 1989), enables us to overcome such dualities. In addition, it enables us to contextualize the formation of professions, by situating it in larger and changing fields of power. Bourdieu's notions of field, habitus, capital are relevant in this respect (e.g. Bourdieu 1986; Schinkel and Tacq 2004; Schinkel 2003, 2007), offering a more integrative and contextualized account of how professional practices are formed.

A profession can be seen as a distinctive, more or less autonomous field, a "social space" held together by sets of institutionalized practices (e.g. Bourdieu 1987, 1993). The medical profession rests upon medical practices, the legal profession on judicial practices, and so on. These practices are relational: they are the cause and consequence of social exchanges, between members of the professions and between professional members and relevant others. Although there is an economic side to these exchanges professionals earn salaries, clients pay for services, and so forth - and 
economic capital is important for structuring interactions, there is more to it than mere economism.

How a field is structured and how services are provided are matters of "accumulated history" (Bourdieu 1986:241). It depends on the appropriation and reproduction of other forms of capital, namely cultural and social capital. Exchanges are not only structured by economic capital, which can be converted into money and institutionalized in the form of property rights. Exchanges are also structured by "dispositions of the mind and body" and "cultural goods" institutionalized in the form of educational qualifications (cultural capital). In addition, exchanges are structured as well by social obligations, networks and connections, which might be institutionalized in the form of titles and credentials (social capital). The heavy investments in association, education, codes and jurisdictions by the professions are aimed at strengthening both forms of capital.

Although the reproduction of capital is never guaranteed (Bourdieu 1986:252-254), these (costly) investments are legitimated, also symbolically, by the very same accumulated forms of cultural and social capital. When this occurs social groups (such as professions) have managed to secure symbolic capital, "which is the form that the various species of capital assume when they are perceived as legitimate" (Bourdieu 1989:17).

This has forceful consequences. Within a profession, the professional is not only educated in a technical sense. He or she is also socialized into a group as a member and really "becomes" a professional in an embodied sense. Over time he or she will develop a socially constituted capacity to act and acquire a professional habitus, a set of dispositions that influences how he or she perceives, thinks and acts. This embodiment of capital is more than subjective; it is influenced by objective social structures, not only within a (professional) field but also in society, such as class, family and (earlier) education.

Professional capital, in other words, must be acquired in order to become professional, but available distributions of economic, cultural and social capital determine who is able to acquire such capital and how this is done. In terms of the dualities identified above, this means that forming and reproducing professions depend on preexisting and evolving power relations. In order to reproduce professional practices, economic capital must be appropriated, and these (reproduced) practices must be legitimated in one way or the other. It also implies that forming professions is 
neither a material affair, nor a symbolic affair, but both material and symbolic.

In more analytical terms, economism and semiologism are interdependent (Bourdieu 1986:252-253). It furthermore means that professionalism rests upon (reproduced) micro-practices even as these practices are being socially (re)constituted by macro-structures, such as fields, class and wider contexts. When we regard professionalism as a form of symbolic capital, we therefore see this symbolic capital as continuously at stake both within professional fields - where its legitimate substance is contested - and within the larger field of power. In the latter, professional fields compete for social status with other fields. Here professionalism is more fundamentally at stake because it is a challenged form of symbolic capital, of recognized status per se.

Agents within professional fields produce actions and interpretations on the basis of acquired but durable embodied dispositions (Bourdieu 1977:72). These dispositions are part of the habitus, which is a "product of history" (Bourdieu 1990:54). Yet, at the same time, these dispositions also embody the practical sense that generates new practices through a logic of distinction, that is, through the production of belief (Bourdieu 1993 ) in practices that are, in the end, based on arbitrary differences.

\section{Pressured Professionalism}

Bourdieu's analytical tools become more relevant when recent developments in professional fields are studied. Professionalism has become a contested notion. Professionals have become "persecuted" (e.g. Farrell and Morris 2003) and professional services are "de-professionalized" (e.g. Broadbent et al. 1997). Certain "outsiders" - especially managers - are held responsible (e.g. Farrell and Morris 2003:136). As the carriers of "Managerialism" (e.g. Enteman 1993), they have to improve professional services by reducing the isolated and autonomous nature of professional service provision. Ironically, managers themselves try to isolate themselves from organizational surroundings, and they try to establish managerial autonomies, by consciously "professionalizing" management (e.g. Grey 1997; Hodgson 2002, 2005; Noordegraaf 2006, 2007). They build professional manager associations, educational programs (like MBA programs), work 
codes (e.g. competency profiles), and secure privileges (e.g. holding professionals to account), in order to improve managerial work and improve professional services.

Before we turn to the rise of professional managers, we elaborate on the resulting pressures and "attacks" on professionalism. In most service sectors throughout the Western world managerial pressures can be witnessed (for instance Freidson 1984; Broadbent et al. 1997; Hafferty and Light 1995; Kitchener et al. 2000; Leicht and Lyman 2006; Gleeson and Knights 2006; Duyvendak et al. 2006; Noordegraaf 2007). These pressures take multiple forms: (a) professional standards are objectified, (b) professionals face a tightening of organizational connections, and (c) professionals become part of corporate and well-managed organizational structures.

First, it is increasingly difficult for professionals to maintain traditional occupational standards, and many standards are "managerialized." In classic professional fields like medicine, work standards have been redesigned. They have become more "evidence-based," for instance, stressing the importance of proven effectiveness of professional behaviors (e.g. Timmermans and Kolker 2004). This serves organizational objectives, as well as accountability ends: managers can steer performances on the basis of effectiveness, and organizations can show their performances to outside worlds (e.g. Timmermans and Berg 2003). In addition, standards become more production-oriented. In addition to (objectified) medical standards, medical doctors must follow new standards, such as standards for optimizing budgetary performance or client satisfaction (e.g. Harrison 2009). This can then be monitored by medical institutions, and used for improving performances.

Finally, professionals themselves are slowly reconfigured through the rise of new educational and occupational standards. Medical education, for example, changes. Who enters educational programs might be redefined, and how medicine is taught might be changed, in order to prepare students for new (organizational) realities. Many medical programs have adopted problem- and competency-based approaches, for example (e.g. Noordegraaf 2010), which are managed by educational managers. Moreover, career standards change: instead of well-defined classic medical careers, medical professionals face new career paths (e.g. Leicht and Fennell 2001), with more emphasis on flexibility, work times and worklife connections. These changes might run together. In the UK, for exam- 
ple, the Modernizing Medical Careers (MMC) program is changing both educational and career trajectories of medical students (Muzio 2009; Wallenburg et al. 2010).

Second, roles and positions of professionals are changing, new professional positions are created, and professionals are tightly connected to organizations (compare Evetts 2009). It has become increasingly difficult to act "freely" and autonomously within service organizations. Increasingly, professionals like medical doctors are tied to organizational surroundings by strategic plans, financing and accountability systems, and performance measurements (e.g. Harrison 1999; Harrison and Pollitt 1994; Van der Veen 2010). Policy-based systems, such as Diagnosis Related Treatment Groups (DRG) (e.g. Fetter and Freeman 1986; Smullen 2010) draw medical doctors into output-oriented control logics. This is reinforced by external pressures on medical institutions. Driven by both Inspectorates and journalists, medical performances are made "transparent," and hospitals and doctors are rated and ranked in newspapers or on websites (e.g. Meijer 2007). In addition, professional roles are "managerialized" as well, either because medical doctors are given managerial responsibilities, or because doctors partly become managers. "Medical managers," for example, have become active throughout Western health care (e.g. Llewellyn 2001).

Third, professionals might become part of well-managed corporate organizational structures. They might become normal employees of "professional service firms" and "managed professional businesses" (Brock et al. 2001; Greenwood et al. 2006). Such large and corporate organizations might even be active on international playing fields (e.g. Faulconbridge and Muzio 2008), reinforced by the internationalization of service sectors and increasing global competitiveness (see a special issue of Organization Studies, 1996, $\mathrm{nr}$ 4). Apart from the internationalization of service firms, the global order in which professional service organizations operate affects professional work. Authors speak of the "corporatization" of professional work (e.g. Smith and Walshe 2004), indicating the spread of corporate models and templates for structuring professional service delivery. This is reinforced by the restructuring of service domains, for instance by the installment of new organizations and institutes that have to monitor, inspect and check service organizations. A good example is the British National Institute for Health and Clinical Excellence (NICE), which 
provides "guidance on public health, health technologies and clinical practice." This is done by collecting evidence on clinical interventions, publishing technology appraisals, setting clear quality standards, and applying the Quality and Outcomes Framework (QOF): ${ }^{2}$

The QOF contains groups of indicators, against which practices score points according to their level of achievement. NICE has been asked to focus on the clinical and health improvement indicators in the QOF, which includes a number of domains such as coronary heart disease and hypertension. The QOF gives an indication of the overall achievement of a practice through a points system.

\section{The Rise of "Professional" Managers}

Managers have become important vehicles for spreading new standards, organizational connections and corporate models in and around professional service organizations (e.g. Farrell and Morris 2003:136-137). They have also become the symbol for new patterns of social control in professional domains like health care. We might even speak of a "second managerial revolution" (cf. Clarke and Newman 1993), which became visible in the 1980s, materialized in the 1990s, and was "felt" at the end of the 1990 s and turn of the century. Increasingly, complaints about managers and examples of manager-professional conflicts have been documented (e.g. Exworthy and Halford 1999; Farrell and Morris 2003). All of this happened fifty years after the first "managerial revolution" (Burnham 1941), accompanying the rise of business enterprise in capitalist economies (Chandler 1977).

The first revolution firmly established managers in social life, and clearly aided the rise of "professional managers." Especially after the Second World War, books like The Management Profession (Allan 1964) appeared, and professional MBA (Master of Business Administration) graduate programs started to blossom and to influence organizational lives (e.g. Useem and Karabel 1986; Reed and Anthony 1992; Mintzberg 2004). The second revolution firmly established "hands-on professional

1) See: http://www.nice.org.uk/aboutnice/qof/qof.jsp (September 2009).

2) See: http://www.nice.org.uk/aboutnice/qof/qof.jsp (September 2009). 
managers" (cf Hood 1991) in public and professional services, such as hospitals, schools, and police forces. These professional service managers are educated through MBA programs but also through other programs, such as MPA (Master of Public Administration), and Master of NonProfit Management programs (e.g. Mirabella and Wish 2000). In addition, they perform other activities in order to "professionalize" their work. They do so literally - by using the word "professional" - as well as institutionally - by building associations, educational programs and work codes for turning members into competent managers.

In different service sectors and countries, groups of managers and highranking executives started to formalize occupational fields, define managerial work, and regulate manager behavior (e.g., Farrell and Morris 2003; Whitchurch 2006; Noordegraaf 2006, 2007). In health care, for example, health care executives and managers are increasingly members of formal manager associations, and they are increasingly managerially educated. In Dutch health care, to take one specific example, around fifty percent of all health care executives have non-medical backgrounds (Noordegraaf et al. 2005). Most of them are members of a manager association, especially the Dutch Association of Health Care Executives (NVZD), and most of them, also including executives with medical backgrounds, have participated in management training programs. More and more, these and other managers seem to be building up managerial careers (e.g. Leicht and Fennell 2001).

As indicated, the rise and "emancipation" of professional service managers is an institutional affair, with classic overtones. In line with traditional professionalization strategies, managers build associations, they set-up educational programs, and they establish work codes in order to standardize technical bases and service ethics. Professional service managers and their associations define the nature of managerial work, list competencies and skills, agree upon codes of conduct, publish magazines, and award prizes. Educational programs, often provided by formal educational institutes, particularly universities, clarify objectives, initiate courses, rely upon certain methods and didactics, and disseminate knowledge and insights.

When we return to Dutch health care executives, this can be illustrated more precisely. In The Netherlands, there is one major association of health care executives, the already mentioned NVZD, and then there are 
also one or two smaller associations. They publish magazines, like " $\mathrm{ZM}$ Magazine;" they publish guidelines, e.g., on salary standards; and they agree upon codes of conduct. They establish links with universities, by sponsoring research and academic chairs; they select and develop educational programs. In The Netherlands, there are several graduate programs for (young) people aspiring to become health care executives, and there are post-graduate and post-academic programs for practicing health care executives. In addition, there are all sorts of non-academic, vocational programs, both at initial and executive levels. In Table 1, these educational modalities are summarized (on the basis of Noordegraaf and Van der Meulen 2008).

\section{Table 1}

Educational programs for Dutch health care managers

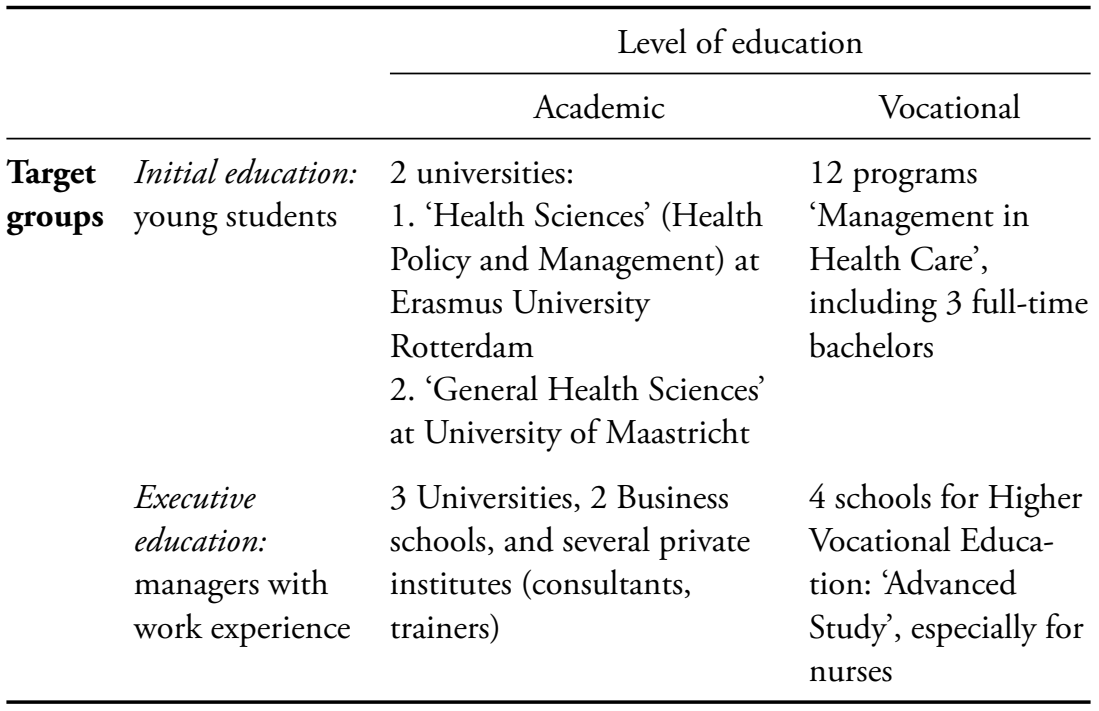

Source: Noordegraaf and Van der Meulen (2008).

These Dutch developments can be compared with professionalization strategies in health care elsewhere. In countries like the UK, the USA, Germany, and France, there are numerous associations for health care managers as well as for other professional service managers, in education, welfare and work, crime and safety. This is illustrated in Table 2. Most of 
these associations are fairly new; they were erected during the 1980s and 1990s. Some have a longer history; they were already building managerial professionalism prior to the 1980 s, or they were acting as labor unions for administrative personnel that became (part of) management during the 1980s and 1990s. In addition, these associations have established interassociational bonds, and new transnational associations have been erected as well. In Europe, for example, Dutch health care executives and their associations are linked to the European Health Management Association (EHMA).

\section{Table 2}

Examples of professional service manager associations

\begin{tabular}{ll}
\hline Service sector & \multicolumn{1}{c}{ Examples of manager associations } \\
\hline Health care & American Association of Healthcare Administrative \\
& Management (AAHAM) \\
& American College of Healthcare Executives (ACHE) \\
& Healthcare Financial Management Association (HFMA) \\
& National Association of Health Services Executives \\
& (NAHSE) \\
& British Association of Medical Managers (BAMM) \\
& Healthcare Financial Management Association (HFMA) \\
& Dutch Association of Healthcare Executives (NVZD) \\
& Dutch Association of Higher Management in Healthcare \\
& (VHMZ) \\
& European Health Management Association (EHMA) \\
& National Association of Elementary School Principals \\
& (NAESP) \\
& National Association of Secondary School Principals \\
& (NASSP) \\
& American Association of School Administrators (AASA) \\
& Association of School and College Leaders (ASCL) \\
& National Association of Headteachers (NAHT) \\
& National Primary Headteachers Association \\
& Allgemeneir Schullleitingsverband Deutschlands \\
& Dutch Association of School Leaders (AVS) \\
& European School Heads Association (ESHA) \\
& International Confederation of Principals (ICP) \\
&
\end{tabular}


Table 2 (cont.)

\begin{tabular}{|c|c|}
\hline Service sector & Examples of manager associations \\
\hline Welfare and work & $\begin{array}{l}\text { American Public Human Service Association (APHSA) } \\
\text { National Association of Public Child Welfare } \\
\text { Administrators (NAPCWA) } \\
\text { Association for Education Welfare Management (AEWM) } \\
\text { Association of Directors of Social Services (ADSS) } \\
\text { Association of Directors of Social Work (ADSW) } \\
\text { L'Association des Directeurs d'Action Sociale et de Santé des } \\
\text { départements (ANDASS) } \\
\text { Dutch Association of Directors of Social Services } \\
\text { (DIVOSA) } \\
\text { Dutch Association of Directors of Child Care (BDKO) }\end{array}$ \\
\hline Crime and safety & $\begin{array}{l}\text { National Association of State Fire Marshals (NASFM) } \\
\text { National Emergency Management Association } \\
\text { The Association of Chief Police Officers (ACPO) } \\
\text { Chief Fire Officers Association (CFOA) } \\
\text { Police Superintendents' Association } \\
\text { Probation Managers Association } \\
\text { Dutch Association of Middle and Higher Police Officials } \\
\text { (VMHP) } \\
\text { The International Association of Fire Chiefs (IAFC) } \\
\text { International Association of Chiefs of Police (IACP) }\end{array}$ \\
\hline
\end{tabular}

There is a certain irony to these developments. Professional managers are not only imitating classic professionals in building professional domains; they are also adopting professional vocabularies, symbols and instruments. Health care managers, for instance, rely upon principles of "evidence-based management" (e.g. Walshe and Rundall 2001), the symbolic and instrumental counterpart of the already-mentioned "evidencebased medicine." They try to define objectified managerial standards on the grounds of proven effectiveness. Managers also rely upon professional terms - most prominently, clients and quality - to frame their plans and projects.

By emphasizing "patient safety" or "high-quality care," managers try to legitimate attempts to install "patient safety systems" and "performance ratings." This is done to meet the presumed demands of changing service 
environments, which they mainly frame in terms of environment-professional dynamics. The American Association of Healthcare Administrative Management (AAHAM), for example, portrays itself as follows:

The American Association of Healthcare Administrative Management (AAHAM) is the premier professional organization in healthcare administrative management. Your one-stop resource centre for information, education and advocacy in the areas of reimbursement, admitting and registration, data management, medical records, patient relations and so much more. [...]

Professional development of its members is one of the primary goals of the association. Publications, conferences and seminars, benchmarking, professional certification and networking offer numerous opportunities for increasing the skills and knowledge that are necessary to function effectively in today's health care environment.

In many ways, all of this is symbolic. Service managers rely upon professional discourses to "put on a professional performance" (cf. Hodgson 2005; compare Watson 2002). But this is also real: the managerialized professional standards mentioned before as well as organizational linkages and corporate models are actually installed on the basis of these discursive acts and arguments. In many hospitals, for example, safety and quality systems have been installed (e.g. Waring and Currie 2009), backed by safety and quality officials, thereby curbing clinical autonomies.

\section{Contests over Capital}

In order to understand what is happening when managers become professional, and why this is happening, functional accounts fall short, and power-centered approaches might be invoked. It might be argued that service managers seek power vis-à-vis service professionals, by isolating their managerial domains and by enhancing their perceived effectiveness and legitimacy (e.g. Grey 1997). This might be analyzed by stressing the "projects" (cf. Hodgson 2005) initiated by managers to build their domains and improve their work. This, in turn, might be explained by referring to the spread of Managerialism, that is, an "ideology of management" (e.g. Enteman 1993) that has pervaded professional service delivery. In many mainstream explanations, this is the dominant account (e.g. Pollitt 1993; Ackroyd et al. 2007). 
The rise of managers is traced back to the late 1970s and early 1980s when neo-liberal policies were advocated, and when Managerialism started to provide templates for organizing professional services. In order to counter the macro-economic problems of the time, economic policies were changed and policy-making and service-provision were rationalized. After a few oil crises and increasing macro-economic problems, the American president Reagan and British prime-minister Thatcher discredited Keynesian policies and embraced monetarism. Such neo-liberal policies went hand in hand with businesslike goal-setting and budget control, value for money, and accountable performances.

It is questionable, however, whether such an account is sufficient. It portrays managers as distinct from and opposed to professionals, and might be too dichotomous: are managers really opposed to professionals? It also portrays managers as "power seekers," and might be too interestbased: are managers merely self-interested? Moreover, it is largely unrelated to context, and might be too self-referential: are managers professionalizing because they struggle with their own professionalism and organizational positions?

This is where Bourdieu might come in. His notions of field, habitus and capital enable us to develop a more integrated understanding of organizational struggles over professionalism - as contests over symbolic capital - in interdependent social fields. His emphasis on larger fields of power, moreover, enables us to contextualize our analysis, to link these contests over symbolic capital to neo-liberal times that economize these interdependencies.

From this perspective, (a) the professionalization of managers is no mere self-interested coincidence but rather a collective effort to govern changing relations and dependencies in and around service organizations; (b) it is not merely about managerial work but rather about the (changing) nature of professional work in changing times; and (c) it is enacted in order to distinguish old from new professional work, especially in neoliberal, economized times. We can elaborate this Bourdieusian perspective as follows.

Managers try to build distinctive professional fields, with "institutionalized practices of education, accreditation, soliciting clients and managing professional employees" (Lawrence 2004:117). This, however, serves a distinctive social "function:" 
According to Bourdieu, fields present themselves synchronically as structured spaces of positions (or posts) whose properties depend on their positions within these spaces. Thus, the analysis of membership in fields is concerned with understanding the development and maintenance of subject positions, rather than with the occupation of those positions by particular organizations or individuals. (Lawrence 2004:117)

In other words, by institutionalizing the practices mentioned, "manager" becomes an occupational category, and the "claims" they "make on society's material and cultural resource base" can be legitimated (cf. Reed and Anthony 1992:596). Those acting in the managerial field can develop their field-specific sens pratique and actors are provided "with resources, interests and opportunities" (Lawrence 2004:117), that is, with capital (or power) that can be exploited. By investing in education, managerial associations try to enhance "scholastic capital" (Useem and Karabel 1986:185), like profit managers did before they invested in MBA programs and credentials. Education might contribute to the cultural capital of service managers. By investing in education, they accumulate knowledge, dispositions and educational qualifications which might influence careers and capacities to manage organizations. By investing in associations, managerial groups try to enhance social capital. They accumulate valuable resources, such as networks, connections and credentials, which might be used to become more effective. By investing in codes, groups try to enhance certain forms of symbolic capital that affect public perceptions and legitimacies. By (re) producing certain vocabularies, profiles, identities and moral symbols, management is advocated as a "responsible" occupation (e.g. Grey 1997).

This is no obvious affair, however. The appropriation and exploitation of - in fact - professional capital is no strict managerial affair. It depends on existing distributions of capital in and around interdependent fields. Managerial professionalization, in other words, is not so much about managers and their capital, but about managers in relation to others, most specifically other professionals. According to Bourdieu actors like managers are no "rational sovereign subjects" (cf. Friedland 2009:887). They are "social operators" in a "plurality of homologously organized fields" (cf. Friedland 2009:887). The strength of managerial professionalism, more practically, comes down to a "mixture of social origin, educational background, success and reputation, employing organization and institutional membership" (Lee 1999:249). 
Whether this succeeds and whether capital "works" depends on the "closeness of interests" and the "parallelism of habitus, arising from similar family and educational backgrounds, fostering kindred world-views" (Bourdieu 1987:842). This has two sides. On the one hand, it concerns potential parallelisms between managers. Although "management" is no homogeneous field, the reproductive mechanism of education will strengthen social and cultural parallelisms, and thereby managers might gain power. On the other hand, it concerns possible parallelisms between managers and professionals, such as medical doctors in hospital surroundings. As has been argued by Brint (1994:11-12), the "professional stratum" has "splintered," not in the least because organizational and market forces have started to affect professional development. Likewise, Leicht and Fennell (1997:217-218) point to "increasingly diverse professional work settings." With the rise of "hybrid" managing professionals (e.g. Waring and Currie 2009), there might even be direct parallelisms, as managers and managing professionals might share social and educational antecedents. They might have comparable middle class backgrounds, and they might have followed comparable management programs.

Contests over symbolic capital, in other words, can be seen as contests over changing interdependencies in and around service organizations. Professionalizing managers try to establish "independence achieved in and through dependence" (cf. Bourdieu 1987:829; compare 1977, 1990), including their dependence on classic professionals.

But there is more to it. Although service managers try to build their own occupation, by invoking forms of traditional professional capital, it is questionable whether they focus exclusively on managerial work. Of course, "the fundamental dynamic of cultural fields is the ongoing production of difference" (Benson 2006:192, italics added), and thus distance (Bourdieu 1996a:34-35), such as that between managerial and medical work. But such "distancing" is only possible on the basis of a relational field in which the greatest differences are nonetheless "in close proximity" because they are part of the same relational field from which they derive their meaning as descriptions of differences and distance (cf. Bourdieu 1994:20).

In simpler terms: service managers are actually busy with reframing and reconfiguring professional work, which implies they must start with actual professional practices but also, at the same time, distance them- 
selves from professional practices. This might really be distancing, like when they speak about professional services in "managerial terms," such as by using words like "targets" and "profits," but it might also be more subtle. This is particularly true when managers try to "integrate" competing professional and managerial logics; proximity and distance might be intertwined. This happens, for example, when they emphasize "dual management," "integrated care," "clinical directors," "medical teams," "patient safety management" and "empowered professionals." These expressions are used to emphasize the importance of professional work, but they also stress the need for transforming professional work. In sum, contests over symbolic capital are not merely contests over changing interdependencies; they are contests over changing professional work and the new interdependencies that flow from it.

This leaves us with a question: why are professional work and its (new) interdependencies changing as they do, and why are managers reacting by appropriating symbolic professional capital? From a Bourdieusian perspective we must answer this question by analyzing larger fields of power and their consequences for appropriating and exploiting capital.

In neo-liberal times, larger fields of power are economized. "Fiscal crises have been features of most states and such crises have been explained by governments as resulting from the rising costs of welfare states and particularly social service professionalism" (Evetts 2003:407). Policymakers have placed professional work against the background of macroeconomic scarcity and have opted for "rationing" service delivery (e.g. Harrison and Hunter 1994). Service organizations have to calculate costs, not in the least because they run financial risks, and they have to seek "competitive advantages" in order not to lose "market share." Professionals must work with organizational systems, not in the least because their salaries increasingly depend on them.

In short, professional services cannot escape the effects of economic capital on service delivery, and thus professional work. This (re)structuring of exchanges will generate resistance to evolving structures (Lawrence 2004:121-123) not only by professionals but also on behalf of managers themselves. Managers try to counter resistance by appropriating professional capital - they will have to "constitute expertise" (cf. Reed and Anthony 1992:597) on managing "society's material and cultural resources." In case of professional services, this is a delicate affair, because of existing 
professional powers and political sensitivities. This explains why service managers seek (classic) professionalism. They seek knowledge, networks and vocabularies in order to accept professionalism, but they distinguish "old" from "new" professional work. The legitimate form of control of economic capital in professional services becomes a form of symbolic capital.

In sum, contests over symbolic capital are not merely contests over changing professional work and the new interdependencies that flow from it. They are also contests over increasingly diverse forms of professional work which are economized but must also remain "professional" in one way or the other.

\section{Conclusion}

Struggles between professionals and managers are one contemporary incarnation of historical struggles over symbolic status in the modern field of power (Bourdieu 1994, 1996b). The autonomization of social fields entails the formation of autonomous occupational groups that monopolize (trans) actions on the basis of the maintenance of entrance/exit borders: standards, education, codes, et cetera. Thus, professional capital is a vehicle of societal status for specific occupational groups. Historically, professionalism is the symbolic capital of the university-educated burghers. These burghers were at the basis of modern society as a liberal democratic, civil society, and gained status on the basis primarily of economic capital. During the nineteenth century, functional differentiation (Luhmann 1997) led to the development of autonomous occupational status groups, primarily of academia and doctors. These groups gained societal status alongside the burghers not on the basis of economic capital but on the basis of professional capital.

The rhetorical core of professionalism entails that the professional is an intrinsically motivated altruistic citizen. The function of professional capital is to supply higher educated occupational groups with the societal status equivalent to their educational capital. This compensates for the lack of economic capital that was the vehicle of mobility for bourgeois capitalists.

The advent of the managerial professional threatens to change this situation. In the struggle over symbolic capital, professional capital has been infiltrated with managerial aspects. The logic of Managerialism has two 
consequences for professions. One consequence is the spread of Managerialism over the entire occupational structure. Increasingly, professions will have managerial aspects: professional standards are managerialized, organizational linkages will tighten, and structures will be corporatized. The second consequence is the procuring of the status of professionalism for managers: managers try to become professional managers in order to improve managerial work and enhance service performance.

This second aspect points at the continued relevance of professionalism as symbolic capital in social struggles over status. After all, when managers seek status, that is, symbolic capital, they seek professional capital. And they do so in the most traditional of ways, by emulating "pure professionalism" (Noordegraaf 2007). But at the same time our discussion has indicated the consequences of the rise of a managerial field for the various professional fields. While Managerialism on the one hand affirms professionalism as symbolic capital, it also, on the other hand seeks in various professional fields to adjust the substance of professionalism. In fact, it claims professional status in managerializing other professions. That is, managerial dispositions have come to be legitimate dispositions for actors in professional fields. At the same time, these tendencies should not be seen as (a) self-interested attempts to become autonomous managers, (b) managerial negations of professional work, and (c) an accidental reordering of service domains.

On the contrary, we have argued that "professional" service managers try to:

(a) become professional managers in order to reconfigure interdependencies, and especially interdependencies between managers and professionals, such as health care executives and medical doctors;

(b) change the nature of professional work in order to face new, increasingly diverse conditions in and around professional work;

(c) appropriate professional capital in order to cope with the economized nature of neo-liberal times, i.e. try to distribute economic capital and material resources in "non-economic" ways.

Here Bourdieu's critique of what he saw as "neo-liberalization" is relevant (Bourdieu 1998, 2000).

It may well be that what is taking place in the field of power is the assertion of a managerial reincarnation of burgher class-power. One might 
say that the struggle between capitalist bourgeoisie and non-bourgeois professionals is taken up once again, and the capitalist monopolization of all forms of symbolic capital looms large. At the same time, this struggle is no longer strictly dichotomous. Contests over economic capital have turned into subtle contests over symbolic capital. The contesters, moreover, might have much more in common than we thought previously. Both managers and professionals increasingly belong to a "splintered" professional middle-class stratum and diverse work settings, at the intersection of occupational, organizational and market spheres.

Such larger questions can be addressed using a perspective on professionalism as symbolic capital. Such a perspective, inspired by Bourdieu but not uncritically relying on his fierce critique of the sociology of the professions, contextualizes both the internal struggles for the substance of symbolic capital as well as the more general contests of professionalism in the field of power. It moreover offers ample promising opportunities for empirical research of contemporary contestations of professional capital. Instead of either studying managers or professionals, and instead of studying their opposition, we should study their interdependencies, and their joint experiences amidst more encompassing social and economic transformations.

\section{References}

Abbott, Andrew. 1988. The System of Professions. An Essay on the Division of Expert Labor. Chicago: The University of Chicago Press.

Ackroyd, Stephan, Ian Kirkpatrick and Richard Walker. 2007. "Public Management Reform and its Consequences for Professional Organisation: A Comparative Analysis." Public Administration 85(1):9-26.

Aldridge, Meryl and Julia Evetts. 2003. "Rethinking the Concept of Professionalism: The Case of Journalism." British Journal of Sociology 54(4):547-564.

Allan, Louis A. 1964. The Management Profession. New York: McGraw-Hill.

Allsop, Judith. 2006. "Regaining Trust in Medicine." Current Socioloqy 54(4):621-636.

Benson, Rodney. 2006. "News Media as a "Journalistic Field": What Bourdieu Adds to New Institutionalism, and Vice Versa." Political Communication 23(2):187-202.

Bourdieu, Pierre. 1977. Outline of a Theory of Practice. Cambridge: Cambridge University Press.

- 1986. "Forms of Capital." In Handbook of Theory and Research for the Sociology of Education, edited by John G. Richardson. New York: Greenwood. 
1987. "The Force of Law: Toward a Sociology of the Juridical Field." The Hastings

Law Journal 38:805-854.

—. 1989. "Social Space and Symbolic Power." Sociological Theory 7(1):14-25.

1990. The Logic of Practice. Cambridge: Polity Press.

1993. The Field of Cultural Production. Cambridge: Polity.

1994. Raisons pratiques. Sur la théorie de l'action. Paris: Seuil.

- 1996a. Distinction; a Social Critique of the Judgement of Taste. Cambridge: Harvard

University Press.

- 1996b. The State Nobility. Elite Schools in the Field of Power. Cambridge: Polity.

. 1998. Acts of Resistance: Against the New Myths of our Time. Cambridge: Polity Press.

—. 2000. Les structures sociales de l'économie. Paris: Seuil.

Bourdieu, Pierre and Loïc Wacquant. 1992. An Invitation to Reflexive Sociology. Cambridge: Polity.

—. 1999. “On the Cunning of Imperialist Reason.” Theory, Culture \& Society 16(1):41-58.

Brint, Steven. 1994. In an Age of Experts: The Changing Role of Professionals in Politics and Public Life. Princeton, NJ: Princeton University Press.

Broadbent Jane, Micahel Dietrich and Jennifer Roberts. 1997. The End of the Professions. New York: Routledge.

Brock, David, Michael Powell and Christopher Robin Hinings, eds. 2001. Restructuring the Professional Organization. London: Routledge.

Bucher, Rue and Anselm Strauss. 1961. "Professions in Process." American Journal of Sociology 66(4):325-334.

Burnham, James. 1941. The Managerial Revolution. Harmondsworth: Penguin.

Carr-Saunders, Alexander Morris. 1928. Professions: Their Organization and Place in Society. Oxford: The Clarendon Press.

Chandler, Alfred Dupont. 1977. The Visible Hand: The Managerial Revolution in American Business. Cambridge, MA: Belknap/Harvard University Press.

Clarke, John and Janet Newman. 1993. "The Right to Manage: A Second Managerial Revolution?" Cultural Studies 7(3):427-41.

Covaleski, Mark A., Mark W. Dirsmith, James B. Heian and Sajay Samuel. 1998. "The Calculated and the Avowed: Techniques of Discipline and Struggles over Identity in Big Six Public Accounting Firms." Administrative Science Quarterly 43:293-327.

Duyvendak, Jan Willem, Trudie Knijn and Monique Kremer, eds. 2006. Policy, People and the New Professional. Deprofessionalisation and Reprofessionalisation in Care and Welfare. Amsterdam: Amsterdam University Press.

Enteman, Willard F. 1993. Managerialism: The Emergence of a New Ideology. Wisconsin: University of Wisconsin Press.

Etzioni, Amitai. 1969. The Semi-Professions and their Organizations. New York: Free Press. Evetts, Julia. 2003. “The Sociological Analysis of Professionalism.” International Sociology 18(2):395-415.

—. 2009. "New Professionalism and New Public Management: Changes, Continuities and Consequences." Comparative Sociology 8:247-266. 
Exworthy, Mark and Susan Halford, eds. 1999. Professionals and the New Managerialism in the Public Sector. Buckingham: OU Press.

Farrell, Catherine and Jonathan Morris. 2003. "The 'Neo-Bureaucratic' State: Professionals, Managers and Professional Managers in Schools, General Practices and Social Work." Organization 10(1):129-56.

Faulconbridge, James and Daniel Muzio. 2008. "Re-Inserting the Professional in the Study of PSFs." Global Networks 7(3):249-270.

Fetter, Robert B. and Jean L. Freeman. 1986. "Diagnosis Related Groups: Product line Management within Hospitals." The Academy of Management Review 11(1):41-54.

Freidson, Eliot. 1984. "The Changing Nature of Professional Control." Annual Review of Sociology 10:1-20.

— 1994. Professionalism Reborn. Cambridge: Polity.

- 2001. Professionalism: The Third Logic. Cambridge: Polity Press.

Friedland, Roger. 2009. "The Endless Fields of Pierre Bourdieu." Organization 16(6): 887-917.

Fournier, Valérie. 1999. "The Appeal to Professionalism as a Disciplinary Mechanism." The Sociological Review 47(2):280-307.

Gleeson, Denis and David Knights. 2006. "Challenging Dualism: Public Professionalism in Troubled Times.” Sociology 40(2):277-295.

Gleeson, Denis, Jenifer Davies and Eunice Wheeler. 2005. "On the Making and Taking of Professionalism in the Further Education Workplace." British Journal of Sociology of Education 26(4):445-460.

Greenwood, Royston, Roy Suddaby and Megan McDougald, eds. 2006. Professional Service Firms. Oxford: Elsevier.

Grey, Christopher. 1997. "Management as a Technical Practice: Professionalization or Responsibilization?” Systems Practice 10(6):703-726.

Hafferty, Frederic W. and Donald W. Light. 1995. "Professional Dynamics and the Changing Nature of Medical Work." Journal of Health and Social Behavior (Extra Issue):132-153.

Hardy, Ian and Bob Lingard. 2008. "Teacher Professional Development as an Effect of Policy and Practice: A Bourdieuian Analysis." Journal of Education Policy 23(1):63-80.

Harrison Stephan. 1999. "Clinical Autonomy and Health Policy: Past and Futures." Pp. 50-64 in Professionals and the New Managerialism in the Public Sector, edited by M. Exworthy and S. Halford. Buckingham: Open University Press.

Harrison, Stephan and David J. Hunter. 1994. Rationing Health Care. London: IPPR.

Harrison, Stephan and Christopher Pollitt. 1994. Controlling Health Professionals. Buckingham: Open University Press.

Hodgson, Damian. 2002. "Disciplining the Professional: The Case of Project Management." Journal of Management Studies 39(6):803-821.

—. 2005. "Putting on a Professional Performance: Performativity, Subversion and Project Management." Organization 12(1):51-68.

Hood, Christopher. 1991. "A Public Management for all Seasons?” Public Administration 69(1):3-19. 
Hoyle, Eric. 1980. "Professionalization and Deprofessionalization in Education." In World Yearbook of Education: 1980: The Professional Development of Teachers, edited by Hoyle, E. and J. Megarry. London: Kogan Page.

Kitchener, Martin. 2000. "The 'Bureaucratization' of Professional Roles: The Case of Clinical Directors in UK Hospitals." Organization 7(1):129-154.

Kitchener, Martin, Ian Kirkpatrick and Richard Whipp. 2000. "Supervising Professional Work under New Public Management: Evidence from an "Invisible Trade"." British Journal of Management 11(3):213-226.

Krause, Elliot A. 1996. Death of the Guilds. New Haven: Yale University Press.

Larson, Magali Sarfatti. 1977. The Rise of Professionalism: A Sociological Analysis. London: University of California Press.

Lawrence, Thomas B. 2004. "Rituals and Resistance: Membership Dynamics in Professional Fields." Human Relations 57(2):115-143.

Lee, Tom. 1995. "Shaping the US Academic Accounting Research Profession: The American Accounting Association and the Social Construction of a Professional Elite." Critical Perspectives on Accounting 6(3):241-261.

- 1999. "Anatomy of a Professional Élite: The Executive Committee of the American Accounting Association 1916-1996." Critical Perspectives on Accounting 10(2):247-264.

Leicht, Kevin T. and Mary L. Fennell. 1997. "The Changing Organizational Context of Professional Work." Annual Review of Sociology 23:215-231.

—. 2001. Professional Work: A Sociological Approach. Malden, MA: Blackwell Publishers.

Leicht, Kevin T. and Elizabeth C.W. Lyman. 2006. "Markets, Institutions, and the Crisis of Professional Practice." Pp. 17-44 in Research in the sociology of organizations: Professional Service Firms, edited by R. Greenwood and R. Suddaby. Oxford: Elsevier JAI Press.

Llewellyn, Sue. 2001. "Two-way Windows: Clincians as Medical Managers.” Organization 22(4):593-623.

Luhmann, Niklas. 1997. Die Gesellschaft der Gesellschaft. Frankfurt/M.: Suhrkamp.

McKenna, Christopher D. 2006. The World's Newest Profession. Cambridge, UK: Cambridge University Press.

Meijer, Albert. 2007. "Understanding Modern Transparency." International Review of Administrative Sciences 75(2):255-269.

- 2007. "Publishing Public Performance Results on the Internet. Do Stakeholders Use the Internet to hold Dutch Public Service Organizations to Account?” Government Information Quarterly 24(1):165-185.

Mintzberg, Henry. 2004. Managers not MBAs. London: Financial Times Prentice Hall.

Mirabella, Roseanne M. and Naomi Bailin Wish. 2000. "The "Best Place" Debate: A Comparison of Graduate Education Programs for Nonprofit Managers." Public Administration Review 60(3):219-229.

Noordegraaf, Mirko. 2006. "Professional Management of Professionals: Hybrid Organisations and Professional Management in Care and Welfare." Pp. 181-193 in Policy, People, and the New Professional, edited by J. W. Duyvendak, T. Knijn and M. Kremer. Amsterdam: Amsterdam University Press. 
2007. "From Pure to Hybrid Professionalism. Present-day Professionalism in Ambiguous Public Domains.” Administration \& Society 39(6):761-785.

— . 2010. "(Re)making Professionals. How Professional Associations Connect Professionalism and Organizations." To be published, Current Sociology.

Noordegraaf, Mirko and Martijn van der Meulen. 2008. "Professional Power Play: Organizing Management in Health Care." Public Administration 86(4):1055-1069.

Noordegraaf, Mirko, Pauline L. Meurs and Annemiek Stoopendaal. 2005. "Pushed Organizational Pulls." Public Management Review 7(1):25-43.

Osiel, Mark J. 1986. "The Professionalization of Journalism: Impetus or Impediment to a "Watchdog” Press." Sociological Inquiry 56(2):163-189.

Parsons, Talcott. 1954. Essays in Sociological Theory. New York: Free Press.

Pollitt, Christopher. 1993. Managerialism and the Public Services: Cuts or Cultural Change in the 1990s? 2nd edn. Oxford: Blackwell.

Randle, Keith and Norman Brady. 1997. "Further Education and the New Managerialism." Journal of Further and Higher Education 21(2):229-239.

Reed, Michael and Peter Anthony. 1992. "Professionalizing Management and Managing Professionalization: British Management in the 1980s." Journal of Management Studies 29(5):591-613.

Schinkel, Willem. 2003. "Pierre Bourdieu's Political Turn?” Theory, Culture \& Society 20(6):69-93.

- 2007. "Sociological Discourse of the Relational: The Cases of Bourdieu and Latour." The Sociological Review 55(4):707-729.

Schinkel, Willem and Jacques Tacq. 2004. "The Saussurean Influence in Bourdieu's Relational Sociology." International Sociology 19(1):51-70.

Schön, Donald A. 1983. The Reflective Practitioner. New York: Basic Books.

Sommerlad, Hilary. 2007. "Researching and Theorizing the Process of Professional Identity Formation." Journal of Law and Society 34(2):190-217.

Smith, Judith and Kieran Walshe. 2004. "Big Business: The Corporatization of Primary Care in the UK and the USA." Public Money and Management 24(2):87-96.

Smullen, Amanda. 2010. "Institutionalizing Professional Conflicts through Financial Reforms: The Case of DBCs in Dutch Mental Healthcare." In Professionals Under Pressure, edited by M. Noordegraaf and B. Steijn. Amsterdam: Amsterdam University Press.

Thomas, Robyn and Annette Davies. 2005. "Theorizing the Micro-politics of Resistance: New Public Management and Managerial Identities in the UK Public Services." Organization Studies 26(5):683-706.

Timmermans Stefan and Marc Berg. 2003. "The Practice of Medical Technology." Sociology of Health \& Illness 25:97-114.

Timmermans, Stefan. and Emily S. Kolker. 2004. "Evidence-Based Medicine and the Reconfiguration of Medical Knowledge." Journal of Health and Social Behavior 45: 177-193.

Torstendahl, Rolf and Michael Burrage, eds. 1990. The Formation of Professions. Knowledge, State and Strategy. London: Sage.

Useem, Michael and Jerome Karabel. 1986. "Pathways to Top Corporate Management." American Sociological Review 51(2):184-200. 
Van der Veen, Romke. 2010. “A Managerial Assault on Professionalism?” In Professionals under Pressure, edited by M. Noordegraaf and B. Steijn. Amsterdam: AUP, to be published.

Wallenburg, Iris, Antoinette A. De Bont, Fedde Scheele and Pauline L. Meurs. 2010. "Reconfiguring Professional Jurisdictions: the Enactment of Transparancies in Medical Training." Unpublished paper for the Annual Meeting of the Society for Social Studies of Science, 2010.

Walshe, Kieran and Thomas G. Rundall. 2001. "Evidence-based Management: From Theory to Practice in Health Care." Milbank Quarterly 79(3):429-457.

Waring, Justin and Graeme Currie. 2009. "Managing Expert Knowledge: Organizational Challenges and Managerial Futures for the UK Medical Profession." Organization Studies 30(7):755-778.

Watson, Tony. 2002. "Professions and Professionalism: Should We Jump Off the Bandwagon, Better to Understand Where It Is Going?" International Studies of Management and Organization, 32(2):94-106.

Whitchurch, Celia. 2006."Who Do They Think They Are? The Changing Identities of Professional Administrators and Managers in UK Higher Education.” Journal of Higher Education Policy and Management 28(2):159-171.

Wilensky, Harold L. 1964. “The Professionalization of Everyone?” American Journal of Sociology 70:137-158. 